\title{
Utilização de serviços de saúde por imigrantes haitianos na grande Cuiabá, Mato Grosso, Brasil
}

\author{
Use of health services by Haitian immigrants in Cuiabá-Mato \\ Grosso, Brazil
}

Jenniffer Francielli de Sousa Alves (https://orcid.org/0000-0002-4836-1855) ${ }^{1}$ Maria Angela Conceição Martins (https://orcid.org/0000-0002-6446-8361) ${ }^{1}$

Fabiano Tonaco Borges (https://orcid.org/0000-0002-7325-6360) ${ }^{2}$

Cássio Silveira (https://orcid.org/0000-0001-7165-1730) ${ }^{3}$

Ana Paula Muraro (https://orcid.org/0000-0001-6237-1673) ${ }^{1}$
${ }^{1}$ Instituto de Saúde

Coletiva, Universidade Federal de Mato Grosso. Av. Fernando Corrêa da Costa 2367, Boa Esperança. 78060900 Cuiabá MT Brasil. jenniffer_sousa-alves@ hotmail.com

${ }^{2}$ Instituto de Saúde Coletiva,

Universidade Federal

Fluminense. Niterói RJ

Brasil.

${ }^{3}$ Faculdade de Ciências Médicas da Santa Casa de São Paulo. São Paulo SP Brasil.

\begin{abstract}
This paper aims to analyze the use of health services by Haitian immigrants in Cuiabá, Mato Grosso. This is a cross-sectional study with a random sample of 452 Haitian immigrants in Cuiabá and Várzea Grande, interviewed between December 2014 and February 2015. Sociodemographic and health characteristics, lifestyle factors, and the use of health services were evaluated. Data analysis included Chi-square test and Poisson regression to investigate the factors associated with the use of health services. We found that $45.6 \%$ of respondents used some health service in Brazil, with a higher prevalence of use among women, those with higher income, longer residence time in Brazil, better understanding of the Portuguese language, and with poor self-reported health. The PHC Unit (UBS) and public urgent and emergency care were the primary services used. We conclude by saying that the SUS assisted the immigrants under the Brazilian constitutional principle of the right to health.
\end{abstract}

Key words International immigration, Haitians, Use health of services, Public health.
Resumo O objetivo deste artigo é analisar a utilização de serviços de saúde por imigrantes haitianos residentes na grande Cuiabá, Mato Grosso. Trata-se de um estudo transversal, com uma amostra probabilística de 452 imigrantes haitianos residentes em Cuiabá e Várzea Grande, entrevistados entre dezembro de 2014 e fevereiro de 2015. Foram avaliadas as características sociodemográficas e de saúde, hábitos de vida e a utilização dos serviços de saúde. Na análise dos dados foram calculados o teste de Qui-quadrado e a Regressão de Poisson para investigar os fatores associados à utilização dos serviços de saúde. Verificou-se que 45,6\% dos entrevistados utilizaram algum serviço de saúde no Brasil, sendo maior a prevalência entre as mulheres, aqueles com maior renda, maior tempo de residência no Brasil, melhor entendimento da lingua portuguesa e que autoavaliaram sua saúde como ruim. Os principais serviços utilizados foram Unidade Básica de Saúde (UBS) e atendimento de urgência e emergência públicos. Conclui-se que os imigrantes foram assistidos pelo SUS em acordo com o princípio constitucional do direito à saúde no Brasil.

Palavras-chave Migração internacional, Haitianos, Haitianas, Uso de serviços de saúde, Saúde pública. 


\section{Introduction}

Haiti is the poorest country in the Americas, aggravated by the earthquake in the Port-au-Prince region in 2010, which destroyed approximately half of the buildings, left 1.5 million people homeless and recorded over 200,000 deaths ${ }^{1}$. In this context, people's way out this situation include emigration to other countries ${ }^{2}$, and Brazil has been a destination for Haitian immigrants since $2010^{3}$. In Brazil, most immigrants headed to the southern and southeastern states, following the country's international migration pattern. However, many settled in the state capital of Mato Grosso which, in turn, was selected as one of the hosting cities of the World Cup in 2014, which generated high demand for workers ${ }^{4}$.

This immigration was triggered by the moment of economic growth that Brazil experienced until 2014, and is a typical case of labor migration $^{5}$. It is still unclear whether cultural factors (especially music and football) favored Haitian emigration to Brazil. Brazil's presence in the United Nations Stabilization Forces of Haiti (MINUSTAH) has often been associated with this migratory process. This information is relevant to health policy planning aimed at ensuring the right to health in Brazil.

The Brazilian Federal Constitution (CF 88) established in its article 196 that "health is a right of all and duty of the State, guaranteed by social and economic policies aimed at reducing the risk of disease and other diseases, and enabling universal access, and egalitarian actions and services for promotion, protection, and recovery"6. Although the Brazilian Constitution ensures the right to health, the phenomenon of immigration has outlined the weak structure and the country's lack of preparedness in migrant health care and also the lack of public health policies aimed at this population?

The concept of using health services encompasses all direct contact, through medical consultations and hospitalizations, or indirectly through preventive and diagnostic tests ${ }^{8}$. From the user's perspective, the reasons that determine the use of health services can be classified as predisposing factors, which are the individual characteristics of the patient, such as age, gender, socioeconomic status; capacity factors, which are the characteristics of the health system, including accessibility; and finally, the need factors, which are defined by the state of health of individuals, their morbidity, risk factors and disabilities. Some studies show that the use of health services by the general pop- ulation is growing, but it still has geographical and social inequalities, and a lower level of use is observed in low-income groups and lower levels of education ${ }^{10-12}$.

Thus, knowledge of the pattern of use of these services becomes essential, as it allows the allocation and generation of resources fairly and effectively ${ }^{13}$. However, after searching the literature, a need for studies on the use of health services among international immigrants in Brazil was identified, especially in the central region of the country and on Haitian immigrants, as this is a recent reality. Thus, this study aimed to analyze the use of health services by Haitian immigrants living in Cuiabá, capital of Mato Grosso, and the sociodemographic factors associated with this use

\section{Materials and methods}

This is a cross-sectional study with a probabilistic sample of Haitian migrants living in Cuiabá and Várzea Grande, considered in this study as Grande Cuiabá. Lwanga and Lemeshow ${ }^{14}$ procedures were adopted to calculate the sample, and the number of Haitian migrants received by the Cuiabá Pastoral Center for Migrants from 2012 to 2014 was considered for the calculation (N $=1059,16 \%$ of them females), $50 \%$ prevalence, significance level of $95 \%$ and a tolerable error of $4 \%$, reaching 383 individuals. Considering the possible losses, $15 \%$ (57 individuals) of the sample size were added to the calculation, resulting in a total of 440 individuals required to establish the study population (370 men and 70 women). Data collection excluded individuals who might have had a cognitive deficit or physical disability that hindered their interview.

Data was collected from December 28, 2014 to February 2, 2015, and interviews were conducted by bilingual interviewers (Creole/Portuguese), trained and under the supervision of the researchers. The research subjects were contacted by telephone or in-person and invited to participate in the research, with telephone contacts and addresses obtained from the Centro Pastoral para Migrantes (CPM). A religious order of the Catholic Church called Scalabrinians runs the CPM. Respondents answered a questionnaire containing 10 information groups.

In this study, the practices adopted when requiring health care were evaluated by the question "Here in Brazil, when you get sick, what kind of help do you seek?". Regarding the use of 
Brazilian health services, the research subjects were asked if they had to use any health service in Brazil, what type of service was used (emergency, hospital, outpatient clinic, dental clinic, primary health care) and what is the management of the service. Also, the proportion of immigrants who had private health insurance and who had already used Brazilian immunization services was evaluated.

From the use and adaptation of the Andersen and Newman model ${ }^{11}$, we analyzed the following predisposing variables: gender (female/male), age ( $<26$ years; $26-35$ years; $36-45$ years; and 45 years and over); marital status (in two categories: married/with partner or single/separated/widowed); education (in three categories: up to complete elementary school, incomplete high school and complete high school or more); working at the time of the survey (yes/no); length of residence in Brazil (less than 30 days, between one month and one year and one year or more); languages you speak/understand (Haitian Creole, Creole and one other language only, Creole and two or more other languages); and understanding the Portuguese language (classified as very little; little; fairly, well or very well).

Among the enabling and need variables, we evaluated individual income (in reais, referring to the last month, later transformed into minimum wages); with private health insurance (yes/ no); self-reported chronic disease; continuous medication use; self-reported health condition; and whether respondents considered that their health changed after emigrating to Brazil.

Data collected through the survey were double-entered and validated using Epi Info 7 software. Quantitative data analysis was performed with SPSS software (version 23). Chi-square test was used to test differences between proportions, adopting significance at 5\% level. Unadjusted Poisson regression was used to verify the association of each factor with the use of health services. Finally, variables with significance in the simple model were taken to the multiple regression model.

The study was approved by the Ethics Committee of the Júlio Muller University Hospital of the Federal University of Mato Grosso, and all individuals who agreed to participate signed the Informed Consent Form before data collection.

\section{Results}

In total, 452 Haitians were interviewed during data collection, of which $82.5 \%$ males and $44.3 \%$ in the 26-35 years' age group. Less than half of respondents reported having used any health service in Brazil (45.6\%). Concerning the health care type they sought when needed, $38.9 \%$ of Haitians interviewed reported never felt the need to do so $(43.2 \%$ of men and $19.0 \%$ of women). Among the women interviewed, $57.0 \%$ reported seeking public health services, with a higher proportion of women reporting continuous medication use $(14.3 \%$ vs. $3.2 \%$ among men; p-value $<$ $0.01)$ and having some chronic disease ( $15.2 \%$ vs. $2.1 \%$ among men; $\mathrm{p}$-value $<0.01$ ). Among Haitians who reported consuming continuous medication, $85.0 \%$ affirmed they acquired them with their resources (Table 1).

Of the 18 Haitians who reported having a chronic disease or condition, $14(70.0 \%)$ said they were hypertensive. The other diseases reported were: asthma (1), diabetes (1), heart disease (1), and migraine (1). Also, 13 of the 18 Haitians who reported having a disease used a health service in Brazil, and only four reported having been seen at primary health care (PHC) and seven at public emergency units (data not shown in table or figure).

Regarding the use of health services (Table 2), the prevalence of health services use was higher among women (PR: 1.59; 95\% CI: 1.642.18) and those with higher income (PR: 1.96; 95\% CI: 1.02-3.75). Regarding the understanding of Portuguese, it was observed that the use of health services was twice more prevalent among those who reported speaking and understanding Portuguese fairly, well or very well, when compared to those who understood very little (PR: 2.30; 95\% CI: 1.38-2.96). Also, as expected, the proportion of health service use among those living in Brazil for the longest time was higher, and ten times more prevalent among those who have been living in Brazil for a year or more (PR: 10.72; 95\% CI: 3.41-33.62).

With respect to the types of services and their nature, $21.5 \%$ used PHC services; $18.6 \%$ used public emergency services; only $1.2 \%$ said they had used private emergency care; $1.6 \%$ used a specialized medical clinic; $0.44 \%$ used a public dental clinic; $1.87 \%$ used a private dental clinic (data not shown in table or figure).

Concerning the use as per lifestyle and self-reported health (Table 3 ), $87 \%$ of immigrants who reported using continuous medication (em- 
Table 1. Number and proportion (\%) of Haitians living in Cuiabá-MT, according to the use of health services in Brazil, by sex. Cuiabá-MT, 2014-2015.

\begin{tabular}{|c|c|c|c|c|c|c|c|}
\hline & \multicolumn{2}{|c|}{ General } & \multicolumn{2}{|c|}{ Male } & \multicolumn{2}{|c|}{ Female } & \multirow[t]{2}{*}{ p-value ${ }^{a}$} \\
\hline & $\mathbf{N}$ & $(\%)$ & $\mathbf{n}$ & $(\%)$ & $\mathbf{n}$ & $(\%)$ & \\
\hline Source of health care ${ }^{b}$ & & & & & & & not applicable \\
\hline Not applicable/never felt ill in Brazil & 176 & $(38.9)$ & 161 & $(43.2)$ & 15 & $(19.0)$ & \\
\hline Public Health Services & 168 & $(37.2)$ & 123 & $(33.0)$ & 45 & $(57.0)$ & \\
\hline Self-medication & 75 & $(16.6)$ & 61 & $(16.4)$ & 14 & $(17.7)$ & \\
\hline $\begin{array}{l}\text { Self-medication and Public Health } \\
\text { Services }\end{array}$ & 12 & $(2.7)$ & 12 & $(3.2)$ & - & - & \\
\hline Private health services & 10 & $(2.2)$ & 8 & $(2.1)$ & 2 & $(2.5)$ & \\
\hline Public and Private Health Services & 6 & $(1.3)$ & 5 & $(1.3)$ & 1 & $(1.3)$ & \\
\hline $\begin{array}{l}\text { Self-medication and Private Health } \\
\text { Services }\end{array}$ & 2 & $(0.4)$ & 1 & $(0.3)$ & 1 & $(1.3)$ & \\
\hline Self-medication and others & 2 & $(0.4)$ & 1 & $(0.3)$ & 1 & $(1.3)$ & \\
\hline Continuous medication usec & & & & & & & $<0.01$ \\
\hline Yes & 23 & $(5.1)$ & 12 & $(3.2)$ & 11 & $(14.3)$ & \\
\hline No & 425 & $(94.9)$ & 359 & $(96.8)$ & 66 & $(85.7)$ & \\
\hline How do you buy medicines for continuc & us used & & & & & & not applicable \\
\hline Own resources & 17 & $(85.0)$ & 10 & $(90.9)$ & 7 & $(77.8)$ & \\
\hline By SUS & 3 & $(15.0)$ & 1 & $(9.1)$ & 2 & $(22.2)$ & \\
\hline Has any chronic disease (self-reported) & & & & & & & $<0.01$ \\
\hline Yes & 18 & $(4.0)$ & 6 & $(1.6)$ & 12 & $(15.2)$ & \\
\hline No & 432 & $(96.0)$ & 365 & $(98.4)$ & 67 & $(84.8)$ & \\
\hline Health insurance & & & & & & & 0.80 \\
\hline Yes & 87 & $(19.2)$ & 71 & $(19.0)$ & 16 & $(20.3)$ & \\
\hline No & 365 & $(80.8)$ & 302 & $(81.0)$ & 63 & $(79.7)$ & \\
\hline Vaccine in Brazil & & & & & & & 0.65 \\
\hline Yes & 305 & $(67.5)$ & 250 & $(67.0)$ & 55 & $(69.6)$ & \\
\hline No & 147 & $(32.5)$ & 123 & $(33.0)$ & 24 & $(30.4)$ & \\
\hline Brazilian vaccination card & & & & & & & 0.59 \\
\hline Yes & 303 & $(67.0)$ & 248 & $(66.5)$ & 55 & $(69.6)$ & \\
\hline No & 149 & $(33.0)$ & 125 & $(33.5)$ & 24 & $(30.4)$ & \\
\hline
\end{tabular}

ployed in the treatment of chronic diseases) used health services, $19.2 \%$ of the general population had private health insurance and of these, $49.4 \%$ used health services in Brazil, with a higher prevalence of use among those who self-reported poor health (PR: 1.56; 95\% CI: 1.05-2.32) and considered that health changed after emigrating to Brazil (PR: 1.57; 95\% CI: 1.19-2.07).

Females, a better understanding of the Portuguese language, and more extended residence in Brazil remained associated with health service use (Table 4) in the mutually adjusted model.

\section{Discussion}

The use of health services among Haitians residing in Cuiabá was more prevalent among women, those with higher income, more extended residence in Brazil, who self-reported poor health and who perceived changes in their health after emigrating to Brazil. Most reported seeking public health services when needed and the leading service used was PHC.

Although the Federal Constitution ensures the right to health, the relevance of analyzing the 
Table 2. Prevalence of use of health service in Brazil among Haitians, according to predisposing variables for health service utilization. Cuiabá-MT, 2014-2015.

\begin{tabular}{|c|c|c|c|c|c|c|}
\hline & \multicolumn{2}{|c|}{ General } & \multicolumn{4}{|c|}{ Use of health services in Brazil } \\
\hline & n & $(\%)$ & $\mathbf{n}$ & $(\%)$ & PR & $95 \% \mathrm{CI}$ \\
\hline \multicolumn{7}{|l|}{ Sex } \\
\hline Male & 373 & $(82.5)$ & 154 & $(41.3)$ & 1.00 & - \\
\hline Female & 79 & $(17.5)$ & 52 & $(65.8)$ & 1.59 & $(1.64-2.18)$ \\
\hline \multicolumn{7}{|l|}{ Age rangeb } \\
\hline 25 years or less & 71 & $(15.7)$ & 31 & $(43.7)$ & 1.00 & - \\
\hline $26-35$ years & 200 & $(44.3)$ & 93 & $(46.5)$ & 1.06 & $(0.71-1.60)$ \\
\hline $36-45$ years & 141 & $(31.3)$ & 65 & $(46.1)$ & 1.05 & $(0.69-1.62)$ \\
\hline Over 45 years & 39 & $(8.6)$ & 17 & $(43.6)$ & 1.00 & $(0.55-1.80)$ \\
\hline \multicolumn{7}{|l|}{ Education b } \\
\hline $\mathrm{K}-8$ & 223 & $(50.8)$ & 101 & $(45.3)$ & 1.00 & - \\
\hline Incomplete high school & 164 & $(37.4)$ & 71 & $(43.3)$ & 0.96 & $(0.70-1.29)$ \\
\hline High school or more & 52 & $(11.8)$ & 26 & $(50.0)$ & 1.10 & $(0.72-1.70)$ \\
\hline \multicolumn{7}{|l|}{ Civil Status c } \\
\hline Married/with partner & 302 & $(66.8)$ & 137 & $(45.4)$ & 1.00 & - \\
\hline Single, widowed, or divorced & 150 & $(33.2)$ & 69 & $(46.0)$ & 1.01 & $(0.76-1.35)$ \\
\hline \multicolumn{7}{|l|}{ Understand Portugueseb } \\
\hline Very little & 210 & $(16.2)$ & 61 & $(29.0)$ & 1.00 & - \\
\hline Little & 80 & $(28.8)$ & 47 & $(58.8)$ & 2.14 & $(1.54-2.96)$ \\
\hline Fairly, well or very well & 148 & $(7.3)$ & 92 & $(62.2)$ & 2.30 & $(1.38-2.96)$ \\
\hline \multicolumn{7}{|l|}{ Languages you speak/undestand } \\
\hline Haitian creoule & 88 & $(19.5)$ & 35 & $(39.8)$ & 1.00 & - \\
\hline Creoule and other language & 146 & $(32.3)$ & 57 & $(39.0)$ & 0.98 & $(0.64-1.49)$ \\
\hline Creoule and two or more others language & 218 & $(48.2)$ & 114 & $(52.3)$ & 1.31 & $(0.90-1.92)$ \\
\hline \multicolumn{7}{|l|}{ Time of residence in Brazil b } \\
\hline Less than 30 days & 49 & $(10.9)$ & 3 & $(6.1)$ & 1.00 & - \\
\hline Betwenn 30 days and 1 year & 177 & $(39.3)$ & 54 & $(30.5)$ & 4.98 & $(1.55-15.93)$ \\
\hline 1 year or more & 224 & $(49.8)$ & 147 & $(65.6)$ & 10.72 & $(3.41-33.62)$ \\
\hline \multicolumn{7}{|l|}{ Current work in Brazil } \\
\hline Yes & 238 & $(52.7)$ & 114 & $(47.9)$ & 1.00 & - \\
\hline No & 214 & $(47.3)$ & 92 & $(43.0)$ & 1.11 & $(0.85-1.47)$ \\
\hline
\end{tabular}

${ }^{a}$ Andersen e Newman (2003) ${ }^{\text {b }}$ missing information: age - 1 respondent; education level: for 13 individuals; understanding of the Portuguese language: 14 individuals; income in the last month - 22 individuals who declined to inform; Length of residence in Brazil - 2 individuals ${ }^{c}$ Only 6 reported being separated (or divorced) and 3 reported being widowed.

use of health services in this population is outlined, as immigrants are considered as a social group generally exposed to a wide range vulnerability situations ${ }^{15}$. Specifically among the evaluated Haitians, the high proportion of immigrants with low education and who were unemployed at the time of the survey, along with other possible situations such as lack of affective bonds in their destination, communication difficulties, poor housing conditions, work, food and geographical distance from family and friends can result in physical and mental illness ${ }^{15,16}$. Also, considering the proportion of employed individuals, a study conducted with the same population to evaluate the working conditions found that the two main sectors into which the Haitians were incorporated were construction and services, which are among the main branches of accidents and occupational diseases in Brazil ${ }^{17}$.

The greater use of health services among the Haitian women interviewed can be considered as a characteristic frequently observed in other population groups. Studies conducted in the American population ${ }^{18}$ and with Brazilians ${ }^{19}$ also observed this association. This may be because women seek more health services for routine screening for preventive or prenatal care, as observed in a study with Bolivians in São Paulo, 
Table 3. Use of health service in Brazil among Haitians according to enabling and necessary variables for health service utilization. Cuiabá-MT, 2014-2015.

\begin{tabular}{|c|c|c|c|c|c|c|}
\hline & \multicolumn{2}{|c|}{ General } & \multicolumn{4}{|c|}{ Use of health services in Brazil } \\
\hline & $\mathbf{n}$ & $(\%)$ & $\mathbf{n}$ & $(\%)$ & $\mathbf{R P}$ & IC $95 \%$ \\
\hline \multicolumn{7}{|c|}{$\begin{array}{l}\text { Income in the last month (considering } \\
\text { minimal wages_-BRL } 724.00 \\
\text { [approximately US\$272.00]) }\end{array}$} \\
\hline None & 136 & $(30.1)$ & 51 & $(37.5)$ & 1.00 & - \\
\hline$\leq 724.00$ reais & 71 & $(15.7)$ & 34 & $(47.9)$ & 1.27 & $(0.83-1.97)$ \\
\hline Between 725.00 and 1500 reais & 208 & $(46.0)$ & 108 & $(51.9)$ & 1.38 & $(0.99-1.93)$ \\
\hline$>1500.00$ reais & 15 & $(3.3)$ & 11 & $(73.3)$ & 1.96 & $(1.02-3.75)$ \\
\hline \multicolumn{7}{|l|}{ Health insurance } \\
\hline No & 365 & $(80.7)$ & 163 & $(44.7)$ & 1.00 & - \\
\hline Yes & 87 & $(19.2)$ & 43 & $(49.4)$ & 0.97 & $0.80-1.17$ \\
\hline \multicolumn{7}{|c|}{ Has any chronic disease (self-reported) } \\
\hline No & 432 & $(96.0)$ & 194 & $(44.7)$ & 1.00 & \\
\hline Yes & 18 & $(4.0)$ & 12 & $(66.7)$ & 1.25 & $0.85-1.83$ \\
\hline \multicolumn{7}{|l|}{ Continuous medication use $\mathrm{b}^{\mathrm{b}}$} \\
\hline No & 425 & $(94.0)$ & 184 & $(43.3)$ & 1.00 & - \\
\hline Yes & 23 & $(5.1)$ & 20 & $(87.0)$ & 0.72 & $0.49-1.06$ \\
\hline \multicolumn{7}{|l|}{ Self-rated health } \\
\hline Excellent or very good & 122 & $(27.0)$ & 51 & $(41.8)$ & 1.00 & - \\
\hline Good & 105 & $(23.2)$ & 50 & $(47.6)$ & 1.14 & $(0.77-1.68)$ \\
\hline Regular & 153 & $(33.8)$ & 58 & $(37.9)$ & 0.91 & $(0.62-1.32)$ \\
\hline $\mathrm{Bad}$ & 72 & $(15.9)$ & 47 & $(65.3)$ & 1.56 & $(1.05-2.32)$ \\
\hline \multicolumn{7}{|l|}{ Health changed after arrival in Brazil } \\
\hline No & 235 & $(52.0)$ & 84 & $(35.7)$ & 1.00 & - \\
\hline Yes & 217 & $(48.0)$ & 122 & $(56.2)$ & 1.57 & $(1.19-2.07)$ \\
\hline \multicolumn{7}{|l|}{ How heatlh changed } \\
\hline Much better or better & 59 & $(13.1)$ & 24 & $(40.7)$ & 1.00 & - \\
\hline Moderate & 57 & $(12.6)$ & 35 & $(61.4)$ & 1.51 & $(0.90-2.53)$ \\
\hline Worse or much worse & 101 & $(22.3)$ & 63 & $(62.4)$ & 1.53 & $(0.96-2.45)$ \\
\hline
\end{tabular}

where prenatal care was among the main reasons for seeking health services, as more than half of the respondents had become pregnant in Brazil and accessed the system for consultations ${ }^{20}$. Additionally, studies conducted with Haitians in other Brazilian cities, such as Chapecó ${ }^{21}$ and Manaus ${ }^{16}$, showed that pregnancy is an essential phenomenon of bringing immigrant women closer to SUS health services. However, it is emphasized that this data may also be related to the weak situation of health services concerning men's health promotion and prevention actions.

Concerning income, the prevalence of health services use was higher among those with higher earnings. More impoverished individuals have worse access to services, despite the need for better health care, which eventually deepens the in- equality picture ${ }^{22}$. It should be noted that, at the time of the survey, $47.3 \%$ of respondents were not working, and more than half had only completed elementary school (50.8\%).

It was also verified that the time of residence in Brazil is characterized as a probable determining factor for the use of health services, and it may also be related to a greater understanding of the Portuguese language and a greater understanding of the country's health system. Specifically, regarding the language domain, this hypothesis was confirmed in this study by the multiple analysis, when adjusting the understanding of the language by the time of residence in Brazil, and only the latter remained associated with the use of the health service. A study with Bolivian migrants in São Paulo showed that the time of 
Table 4. Prevalence Ratio (PR) and 95\% confidence interval (95\% CI) of the mutually adjusted Poisson Regression Model regarding the use of health services by Haitian immigrants. Cuiabá-MT, 2014-2015.

\begin{tabular}{|c|c|c|}
\hline & PR & $95 \% \mathrm{CI}$ \\
\hline \multicolumn{3}{|l|}{ Sex } \\
\hline Male & 1.00 & - \\
\hline Female & 1.52 & $1.07-2.16$ \\
\hline \multicolumn{3}{|l|}{ Understand Portuguese } \\
\hline Very little & 1.00 & - \\
\hline Little & 1.45 & $1.00-2.12$ \\
\hline Fairly, well or very well & 1.55 & $1.04-2.32$ \\
\hline \multicolumn{3}{|l|}{ Time of residence in Brazil } \\
\hline Less than 30 days & 1.00 & - \\
\hline $\begin{array}{l}\text { Betwenn } 30 \text { days and } 1 \\
\text { year }\end{array}$ & 3.21 & $0.97-10.59$ \\
\hline 1 year or more & 5.69 & $1.72-18.84$ \\
\hline \multicolumn{3}{|l|}{ Income in the last month } \\
\hline None & 1.00 & - \\
\hline$\leq 724.00$ reais & 0.87 & $0.56-1.37$ \\
\hline $\begin{array}{l}\text { Between } 725.00 \text { and } 1500 \\
\text { reais }\end{array}$ & 0.94 & $0.65-1.35$ \\
\hline$>1500.00$ reais & 1.28 & $0.64-2.59$ \\
\hline \multicolumn{3}{|l|}{ Self-rated health } \\
\hline Excellent or very good & 1.00 & - \\
\hline Good & 0.92 & $0.59-1.41$ \\
\hline Regular & 0.79 & $0.51-1.21$ \\
\hline Bad & 1.08 & $0.67-1.76$ \\
\hline \multicolumn{3}{|l|}{$\begin{array}{l}\text { Health changed after arrival } \\
\text { in Brazil }\end{array}$} \\
\hline No & 1.00 & - \\
\hline Yes & 0.72 & $0.52-1.00$ \\
\hline
\end{tabular}

residence in Brazil was associated with the use of different health services, especially primary care, which, in turn, was more employed among those who lived longer in the country ( 5 years or more). Also, in this study, regarding treatment in pharmacies or emergency services, the most extended established immigrant group in Brazil showed a similar pattern to vulnerable Brazilians ${ }^{23}$.

The bond created between the Haitian population and the Community Health Workers by time of residence in Brazil may also contribute to the higher demand for these services, as these professionals are members of the community and are part of the team and households in a given territory ${ }^{24}$.

It should also be considered that, besides the biological aspect related to migratory flows, people not only move across national boundaries but also between and within different medical systems ${ }^{25}$, it may take time to adapt to the new system in the destination country. In Haiti, the Health System is described as a real "Quilt", with a predominance of private health services ${ }^{26,27}$. Health services provided in the Haitian health system cover $60 \%$ of the population, with $40 \%$ adhering to traditional health care practices ${ }^{27}$.

Self-reported health is an essential indicator of health perception, with a considerable proportion of immigrants who affirmed their health was poor and who, in turn, were more likely to use the services. Special consideration should be given to the "healthy migrant" phenomenon characterized by the fact that immigrants have better health conditions than the native population, supposedly due to the "selection" of immigrants, both due to the need for labor markets in the receiving countries and the necessary health, and, sometimes, violent and challenging travel ${ }^{28}$. Another related factor may be the low level of education of this population, given that individuals with higher educational achievement may have better access to health care information, promotion, and prevention, as well as greater adherence to prescribed treatments and also use of health services $^{29}$.

Immigrants undergo various changes during the migration process and the adaptation in their destination that can affect their health positively or negatively. In this study, when asked if their health changed after migrating to Brazil, more than half confirmed this change, and $22.3 \%$ said that health changed for worse or much worse. This significant proportion observed may be related specifically to being a foreigner, since the move to an unknown country, the geographical distance of family, friends and the learning process of new elements of local, regional and national culture may have contributed to the change in health after migrating to Brazil. A study of Hispanic and non-Hispanic, black, white, and Asian immigrants in the United States found that the prevalence of self-reported health was poor with longer residence in the destination country, with no difference regarding ethnic group, although black immigrants faced a more considerable socioeconomic disadvantage when compared to whites and Asians ${ }^{30}$.

When evaluating individuals who reported having a disease or chronic condition, it was found that a small proportion reported having used services in PHC, however, it should be noted that the monitoring of chronic conditions in primary care is of paramount importance, as it 
includes promotion actions, health surveillance, prevention and assistance to patients with these diseases, allowing the creation of a bond between professionals and patients and, consequently, a more effective monitoring of their clinical case ${ }^{31}$.

The leading service used by Haitians was PHC, similar to the study conducted with Bolivians living in São Paulo ${ }^{23}$. We also emphasize the critical proportion of individuals who used some public emergency service. For many users, these services, such as UPAS (Health Care Units) are the gateway to the health system, as they do not require scheduling, thus providing the highest guarantee of care, access to assistance with more significant technological resources and the highest probability of immediate resolution ${ }^{32}$. It is questioned whether all who sought this type of service were included in the target population, or if there were low-complexity cases that could be attended in primary care.

A significant proportion of Haitian migrants said they had private health insurance (19.2\%), and it is worth noting that in Brazil, $27.9 \%$ of the population has a private health insurance ${ }^{33}$. This significant proportion of insured Haitians may be related to the granting of a humanitarian visa by the National Immigration Council (CNIg), which facilitates the necessary documentation for the regularization in the country, unlike other nationalities ${ }^{34}$. The documentation allows the inclusion of these immigrants in the formal labor market, which may be accompanied by benefits to the worker, such as corporate health insurance. Thus, we can see a polarity of characteristics in this population group. In a population with a majority of low socioeconomic status (assessed as education and income in this study), but with a significant proportion being assisted by private health insurance.

This study sought to understand the profile of health service use and associated factors through primary data. The importance of such research is emphasized, since it is not possible to evaluate the services used by foreigners in Brazil through the main SUS Health Information Systems, such as the SIH-SUS (SUS Hospital Information System) and SIA (Ambulatory Information System), given the incomplete information on the patient's nationality in the systems. The importance of completing this field is emphasized, because it would allow access to information regarding the types of services and procedures used by international immigrants, with the possibility of drawing a profile of the use of services by this population.

However, some limitations of this paper should be considered, as it is a cross-sectional study at the local level that sought to understand the essential characteristics of the use of health services, addressing the demand for health services by individuals, not deepening the conditions and determinants of the use of these services and, therefore, hindering the identification of obstacles to comprehensive health care of this population. Thus, this study aims to contribute some basic notes on the subject through primary data.

\section{Conclusion}

Based on the results of this investigation, we conclude that SUS assisted the immigrants under the Brazilian constitutional principle of the right to health. As expected, immigrants who had lived in Brazil longer had a higher rate of services use, because the longer stay favors a greater understanding of the country's health system. The information presented suggests the relevance of studies on the association between vulnerability and health needs in an immigrant population; research on the effect of healthy immigrants in Brazil; compliance with the constitutional principle of integrality in such populations; and studies on international migration (migration factors, travel conditions; factors of attraction to the destination country), social integration and illness.

Again, the importance of knowledge about the pattern of use of health services by immigrants is stressed, due to the need to evaluate public policies considering the vulnerabilities imposed by the migratory situation. It is also essential to incorporate policies, permanent education actions for health professionals, and develop of other forms of communication besides verbal language, which could improve access of this population group to health services.

Also, from 2015, the worsening economic crisis in Brazil has been directly reflected in jobs and causing the movement of Haitians to other states and countries (such as the United States), or even the return to their home country. This transience should be considered in health planning, as it is an extremely dynamic process. 


\section{Collaborations}

JFS Alves and AP Muraro participated in the conception and design of the study, analysis, and interpretation of data, as well as drafting the intellectual content of the manuscript. MAC Martins, FT Borges, and C Silveira participated in the study conception and design, data interpretation, and critical review of the manuscript's intellectual content. All authors approved the final version of the manuscript.

\section{Acknowledgments}

The authors are grateful to the Cuiabá Centro Pastoral para Migrantes (CPM) for giving access to the records of the Haitians who were received, and also supporting the entire research. Special thanks to the research participants and all collaborators (undergraduate and graduate students) who participated in the fieldwork and data tabulation.

This study was funded by the Mato Grosso State Research Support Foundation (FAPEMAT) and the National Council for Scientific and Technological Development (CNPq).

\section{References}

1. Santiago A, organizador. Haiti por si: a reconquista da independência roubada. Fortaleza: Expressão Gráfica e Editora; 2013.

2. Patarra NL. Brasil: país de imigração? In: Fernandes D, Peixoto J (editores). Rev Internacional em Língua Portuguesa. 2011. III Série, No 24, pág. 65.

3. Cotinguiba GC, Pimentel M. l. Wout, raketè, fwontyè, anpil mizèl: reflexões sobre os limites da alteridade em relação à imigração haitiana para o Brasil. Univ Rel Inter 2014; 12(1):73-86.

4. Raye RL, Souza MJB, Viegas LP, Boaria F. A Copa do Mundo 2014: oportunidades e prospecção geradas para a cadeia produtiva do turismo de Cuiabá - MT. Revista de Turismo Contemporâneo 2013; 1(1):59-77.

5. Fernandes D, Ribeiro JC. Migração laboral no Brasil: problemáticas e perspectivas. Cadernos Obmigra 2015; 1(1):15-37.

6. Brasil. Constituição da República Federativa do Brasil de 1988. Diário Oficial da União 1988; 5 out.

7. Filippim ES, Zeni K. Migração haitiana para o Brasil: acolhimento e políticas públicas. Pretexto 2014; 15(12):11-27.

8. Martins M, Travassos C. Uma revisão sobre os conceitos de acesso utilização de serviços de saúde. Cad Saude Publica 2004; 20(Supl. 2):5190-5198.

9. Pineault R. Compreendendo o sistema de saúde para uma melhor gestão. Brasília: Conass; 2016.

10. Gomes KO, Reis EA, Guimarães MDC, Cherchiglia ML. Utilização de serviços de saúde por população quilombola do Sudoeste da Bahia, Brasil. Cad Saude Publica 2013; 29(9):1829-1842.

11. Andersen R, Newman JF. Societal and Individual Determinants of Medical Care Utilization in the United States. Milbank Q 2005; 83:4.

12. Giovanella L, Escorel S, Lobato, LVC, Noronha JC, Carvalho AI. Políticas e sistemas de saúde no Brasil. 2a ed. Rio de Janeiro: Editora Fiocruz/Centro Brasileiro de Estudos de Saúde; 2012.

13. Sawyer DO, Leite IC, Alexandrino R. Perfis de utilização de serviços de saúde no Brasil. Cien Saude Colet 2002; 7(4):757-776.

14. Lwanga SK, Lemeshow S. Sample Size Determination in Health Studies: A Practical Manual. Geneva: World Health Organization (WHO); 1991.

15. Lussi C, Marinuci R. Vulnerabilidade social em contexto migratório. Brasília: Centro Scalabriniano de Estudos Migratórios (CSEM). [acessado 2016 Fev 8]. Disponível em: http://www.csem.org.br/pdfs/vulnerabilidades_dos_migrantes.pdf

16. Santos FV. A inclusão dos migrantes internacionais nas políticas do sistema de saúde brasileiro: o caso dos haitianos no Amazonas. Hist Cienc Saude-Manguinhos 2016; 23(2):477-494.

17. Leão LHC, Muraro AP, Palos CC, Martins MAC, Borges FT. Migração internacional, saúde e trabalho: uma análise sobre os haitianos em Mato Grosso, Brasil. Cad Saude Publica 2017; 33(7):e0018181.

18. Cherry DK, Woodwell DA. National ambulatory medical care survey: 2000 summary. Centers for Disease Control and Prevention, Advanced Data N, 328, June 5, DHHS Publication No. (PHS) 2002- 1250, 02$0379(5 / 02)$. 
19. Pinheiro R, Viacava F, Travassos C, Brito AS. Gênero, morbidade, acesso e utilização de serviços de saúde no Brasil. Cien Saude Colet 2002; 7(4):687-707.

20. Waldman TC. Movimentos migratórios sob a perspectiva do direito à saúde: Imigrantes bolivianas em São Paulo. Rev de Direito Sanitário 2011; 12(1):90114.

21. Risson AP. Cartografia da atenção à saúde de imigrantes haitianos residentes em chapecó, SC [dissertação]. Chapecó: Universidade Comunitária da Região do Chapecó; 2016.

22. Neri M, Soares W. Desigualdade social e saúde no Brasil. Cad Saude Publica 2002. 18(Supl.):77-87.

23. Silveira C, Carneiro Júnior N, Ribeiro MCSA, Barata RCB. Living conditions and access to health services by Bolivian immigrants in the city of São Paulo, Brazil. Cad Saude Publica 2013; 29(10):2017-2027.

24. Oliveira EM, Spiri WC. Programa Saúde da Família: a experiência de equipe multiprofissional. Rev Saude Publica 2006; 40(4):727-733.

25. Sargent C, Larchanché S. Transnational migration and global health: the production and management of risk, illness, and access to care. Annual Review of Anthropology 2011; (40):345-361.

26. Wamai RG, Larkin C. Health development experiences in Haiti: what can be learned from the past to find a way forward? JMAJ 2011; 54(1):56-67.

27. Bordin R, Misoczky MC. Sistema Nacional de Saúde do Haiti - Uma introdução: Caracterização sociodemográfica. In: Barcelos R, Bordin R, Misoczky MC, organizadores. Fortalecimento da rede de serviços de saúde: Um relato da cooperação Brasil/Cuba/Haiti. Porto Alegre: Pubblicato Editora; 2015. p. 27-30.

28. Razum O, Zeeb H, Rohrmann S. The 'Healthy Migrant Effect'- Not Merely a Fallacy of Inaccurate Denominator Figures. Int J Epidemiol 2000; 29(1):199-200.

29. Brasil. Ministério da saúde (MS). Relatório Final da Comissão Nacional sobre Determinantes Sociais da Saúde. As causas sociais das iniquidades em saúde no Brasil. Brasília: MS; 2008. [acessado 2016 Fev 8]. Disponível em: http://bvsms.saude.gov.br/bvs/publicacoes/causas_sociais_iniquidades.pdf

30. Alang SM, Mccreedy EM, Mcalpine DD. Race, Ethnicity, and Self-Rated Health Among Immigrants in the United States. J Racial Ethn Health Disparities 2015; 2(4):565-572.

31. Malta DC, Morais NOL, Silva Júnior JB. Presentation of the strategic action plan for coping with chronic diseases in Brazil from 2011 to 2022. Epidemiol Serv Saúde 2011; 20(4):425-438.

32. Freire AB, Fernandes DL, Moro JS, Kneipp MM, Cardoso CM, Lima SBS. Serviços de urgência e emergência: quais os motivos que levam o usuário aos pronto-atendimentos? Saúde (Santa Maria) 2015; 41(1):195-200.
33. Instituto Brasileiro de Geografia e Estatística (IBGE). Pesquisa Nacional de Saúde 2013: percepção do estado de saúde, estilos de vida e doenças crônicas. Rio de Janeiro: IBGE. [acessado 2016 Fev 8]. Disponível em: http://biblioteca.ibge.gov.br/visualizacao/livros/ liv91110.pdf

34. Fernandes D, Milesi R, Pimenta B, Carmo V. Migração dos Haitianos para o Brasil: a RN no 97/2012: uma avaliação preliminar. Refúgio, Migrações e Cidadania 2013; 8(8):55-60.
Article submitted 04/09/2017

Approved 07/05/2018

Final version submitted 09/05/2018 